\title{
MAML2 Gene
}

National Cancer Institute

\section{Source}

National Cancer Institute. MAML2 Gene. NCI Thesaurus. Code C95456.

This gene plays a role in transcriptional regulation and signal transduction. 